\title{
SOCIALIST ANTI-SEMITISM, DEFENSE OF A BOURGEOIS JEW AND DISCOVERY OF THE JEWISH PROLETARIAT
}

\author{
CHANGING ATTITUDES OF FRENCH SOCIALISTS \\ BEFORE 1914*
}

The anti-Semitism of the mid-nineteenth-century French socialists has often been cited. Charles Fourier saw the Jews as the incarnation of commerce: parasitical, deceitful, traitorous and unproductive. PierreJoseph Proudhon attacked the Jews even more violently, declaring the Jew the incarnation of finance capitalism and "by temperament an anti-producer". The Fourierist Alphonse Toussenel argued in Les Juifs rois de l'époque that finance, that is to say, Jews, were dominating and ruining France, while Auguste Blanqui sprinkled his correspondence with remarks about Jewish usury and "Shylocks", and in a general anticlerical critique blamed the Jews for having given birth to Catholicism, an even greater evil than Judaism. In the late 1860's Gustave Tridon, who was a close follower of Blanqui, wrote a book entitled Du Molochisme juif, in which he also attacked the Jews on anti-religious as well as racial grounds, in addition to using the usual economic terms of disparagement. ${ }^{1}$

Socialist anti-Semitism, just as non-socialist, can be seen to have three modes of expression: economic, "religious" (actually anti-clerical) and racial, although for the socialists the first two would have a particular meaning in their criticism of capitalism and of religion as the "opium of the people". In elaborating their various critiques of contemporary society these early socialists often used the Jews as a symbol of the rise of capitalism. Whether it was commercial or finance capitalism, the Jewish

* I would like to thank M. Rebérioux and J. Rojahn for their very helpful comments on earlier drafts of this article.

${ }^{1}$ For an inventory of anti-Semitic quotes by Fourier, Proudhon, Toussenel, etc., see the following articles by E. Silberner: "Charles Fourier on the Jewish Question", in: Jewish Social Studies, VIII (1946), pp. 245-66; "The Attitude of the Fourierist School Towards the Jews", ibid., IX (1947), pp. 339-62; "Proudhon's Judeophobia", in: Historica Judaica, X (1948), pp. 61-80; "French Socialism and the Jews", ibid., XV-XVI (195354), pp. 4-38; "Anti-Jewish Trends in French Revolutionary Syndicalism", in: Jewish Social Studies, XV (1953), pp. 195-202; and Z. Szajkowski, Antisemitizm in der Frantseyzisher arbeter-bavegung (New York, 1948). 
merchant or financier was seen as the most visible symptom of the malady. The cure ranged from their colonization as farmers (Fourier even became a proto-"Zionist" at the end of his life, proposing that an experimental phalanstery in Palestine be funded by Rothschild!) to their expulsion.

The symptoms of socialist anti-Semitism have been carefully traced by historians of anti-Semitism, historians of the "revolutionary Right" and less carefully by a recent "philosopher" of French national-socialism. ${ }^{2}$ Nor has the problem escaped historians of the Left. ${ }^{3}$ Most authors agree that at the end of the nineteenth century the symptoms of French socialist antiSemitism decline, largely thanks to the Dreyfus Affair and socialist ralliement to the dreyfusard cause. But that rallying to the dreyfusard side was not only (and for some socialists not at all) the defense of a bourgeois Jew, but rather a rallying to the threatened Republic itself, an important outcome of the Affair. ${ }^{4}$

The "cure" of socialist anti-Semitism (even if not complete) needs to be examined more closely in this context in order to understand the expression of the symptoms and the process by which the French socialists had their "consciousness raised" with regard to the Jewish question. At the same time it may be argued that another factor, generally ignored in treatments of socialist attitudes toward anti-Semitism before 1914, was also important in re-evaluating attitudes toward anti-Semitism: the discovery of a "Jewish proletariat". With the massive emigration of Eastern European Jewish workers westward from the 1880's on (including the settlement of some

2 For the first two categories, see the works of L. Poliakov, Histoire de l'antisémitisme (4 vols; Paris, 1955-77), III, pp. 377-91; R. Byrnes, Antisemitism in Modern France (New Brunswick, 1950), pp. 118-25, 156-78; S. Wilson, Ideology and Experience: Antisemitism in France at the Time of the Dreyfus Affair (Rutherford, 1982), pp. 64-72, 181, and ch. 11; and Z. Sternhell, La Droite révolutionnaire (Paris, 1978), pp. 177-214. As for the recent "philosopher"-polemicist of French national-socialism, see B.-H. Lévy, L'Idéologie française (Paris, 1981), particularly pp. 114-39, and the numerous criticisms of Lévy's essay, particularly in Esprit, May 1981, Le Débat, June, and Le Monde, January 16 (B. Poirot-Delpech attacking, among other things, Lévy's a-historicism). See also the interesting article by M. Winock, "La Gauche et les Juifs", in: L'Histoire, No 34 (1981), pp. 13-25, and P. Birnbaum's analysis of anti-capitalist anti-Semitism in Le Peuple et les gros (Paris, 1979), pp. 15-26.

${ }^{3}$ E. Cahm, "Socialism and the Nationalist Movement in France at the Time of the Dreyfus Affair", in: Socialism and Nationalism, ed. by E. Cahm and V. C. Fišera (3 vols; Nottingham, 1978-80), II, pp. 48-64; G. Lichtheim, "Socialism and the Jews", in: Dissent, XV (1968), pp. 314-42; V. M. Glasberg, "Intent and Consequences: The 'Jewish Question' in the French Socialist Movement of the Late Nineteenth Century", in: Jewish Social Studies, XXXVI (1974), pp. 61-71; R. Wistrich, "French Socialism and the Dreyfus Affair", in: Wiener Library Bulletin, Nos 35-36 (1975), pp. 9-20.

${ }^{4}$ N. L. Green, "The Dreyfus Affair and Ruling Class Cohesion", in: Science and Society, XLIII (1979), pp. 29-50. 
40,000 in France), the French socialists had to re-appraise their assumptions about the socio-economic profile of the Jews. ${ }^{5}$ This, along with the Dreyfus Affair, was fundamental in changing socialist attitudes to antiSemitism.

1886 marks the beginning of anti-Semitism as a popular movement in France, with the publication of Edouard Drumont's La France juive. Drumont called to all the disgruntled and ever-swindled, pointing to the Jews as the real cause of their griefs. As Drumont explained, the financial wheelings and dealings of the Jews had caused poverty to all but themselves. In his two-volume tirade (also published in a "popular" one-volume edition) Drumont's complaint against the Jews knew no time boundaries, but his fundamental critique was that the Jews, along with the French Revolution, had destroyed everything that was beautifully French. The Jews, ever since their emancipation at the time of the Revolution, had proceeded to contaminate France through "the introduction of a foreign body into an organism which up until then had been healthy". "La France aux Français" was the motto of Drumont and that of his newspaper, $L a$ Libre Parole.

Drumont's attack on the Jews echoed socialist anti-Semitism in two ways. First of all his major (although not sole) criticism of the Jews had to do with their wealth and their financial power. He was in fact describing the Jews as "Kings of the Epoch" once more, lauding Toussenel as his precursor. According to Drumont, the Jews had sucked the wealth out of France's pockets in order to fill their own gold-lined purses. By re-iterating common socialist phrases against usurers, parasites, Jewish wolves of the Bourse, etc., Drumont followed in the tradition of Proudhon and Toussenel, often quoting them directly.

Yet aside from this condemnation of unproductive wealth, Drumont more clearly exhibited his "socialism" with his own plan for rectifying the wrongs that the Jewish capitalists had visited on France. His solution was twofold. He called for Jewish-owned factories to be the laboratories of social experiments where the workers would take the management and finances into their own hands. And he suggested a re-distribution of Jewish wealth ("biens juifs confisqués") to be administered as the biens nationaux

\footnotetext{
5 For a discussion of the Jewish immigration to France before World War I, see Green, The Pletzl of Paris: Jewish Immigrant Workers in the Belle Epoque (New York, Paris, 1985), especially Appendix A concerning an estimate of the number of immigrants to Paris.

${ }^{6}$ E. Drumont, La France juive (2 vols; Paris, 1886), 1, p. xii; see also M. Winock, Edouard Drumont et Cie.: Essai sur l'antisémitisme et le fascisme en France (Paris. 1982).
} 


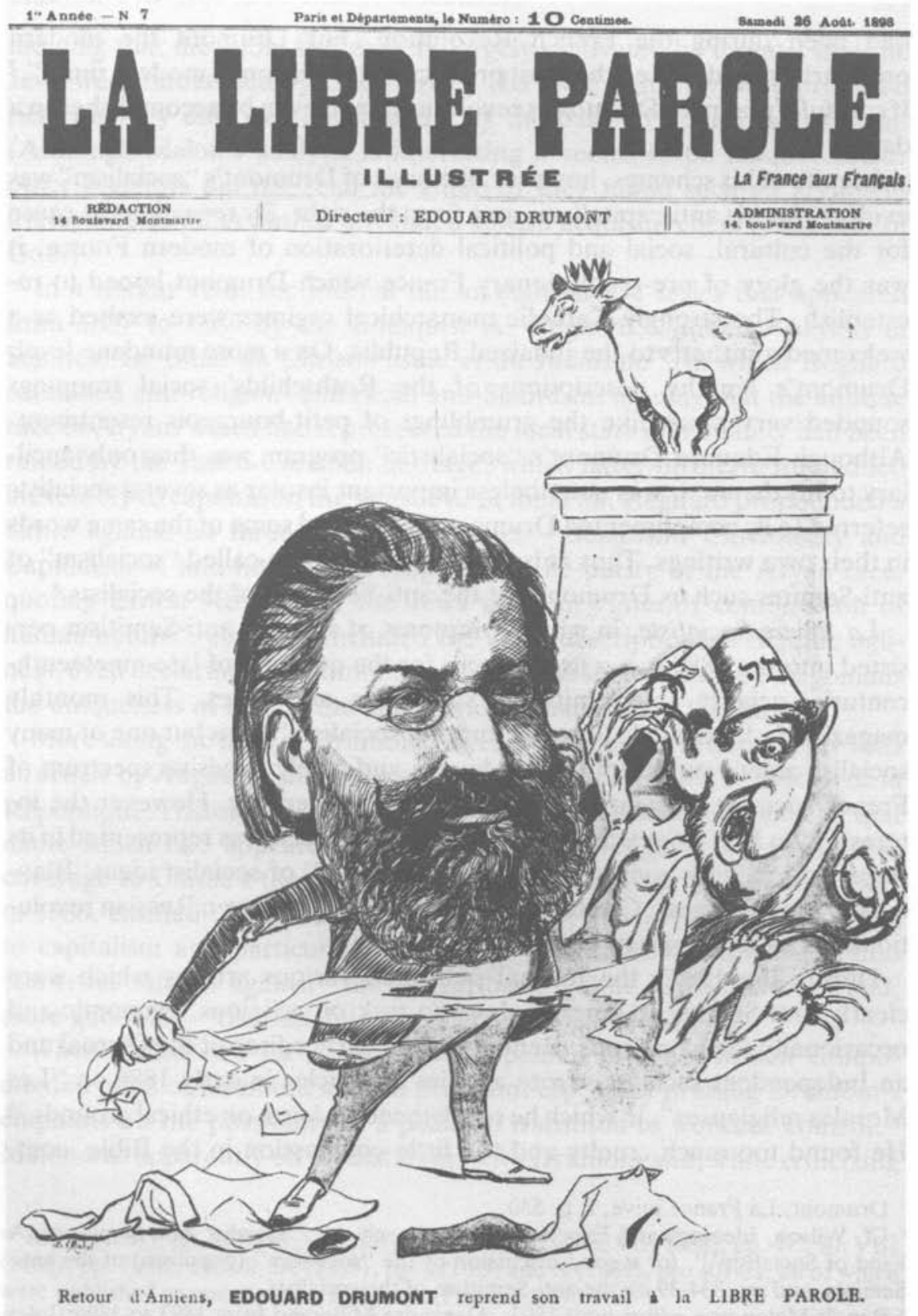

Front page of La Libre Parole Illustrée, 1893, No 7: "Back from Amiens, Edouard Drumont resumes his work at the Libre Parole." 
had been during the French Revolution. For Drumont the modern proletariat could make "the most productive revolution of modern times".? If carefully planned, Drumont's revolution could even be accomplished in a day!

In spite of his schemes, however, the basis of Drumont's "socialism" was evident, for his anti-capitalism came from the right. By revealing the cause for the cultural, social and political deterioration of modern France, it was the glory of pre-revolutionary France which Drumont hoped to reestablish. The strongly Catholic monarchical regimes were exalted as a welcomed antithesis to the judaized Republic. On a more mundane level, Drumont's lengthy descriptions of the Rothschilds' social trappings sounded very much like the grumblings of petit-bourgeois resentment. Although Edouard Drumont's "socialistic" program was thus only ancillary to his theme, it was nonetheless important insofar as several socialists referred to it, complimented Drumont and echoed some of the same words in their own writings. Thus at issue here is not the so-called "socialism" of anti-Semites such as Drumont but the anti-Semitism of the socialists. ${ }^{8}$

La Revue Socialiste, in which symptoms of socialist anti-Semitism persisted into the 1880 's, is a useful focus for the question of late-nineteenthcentury socialist anti-Semitism's symptoms and cures. This monthly magazine (a "recueil de libre élaboration socialiste") was but one of many socialist organs representing the diverse and rarely cohesive spectrum of French socialist thought in the late nineteenth century. However the interest of La Revue Socialiste, is in the variety of socialisms represented in its pages and its very goal to be a "foyer commun" of socialist ideas. Blanquists, Independents, Guesdists (until the 1890's) and even Russian revolutionaries were among its contributors. ${ }^{9}$

During the 1880's the journal published various articles which were clearly anti-Semitic, taking the Jews to task on religious, economic and occasionally racial grounds. Benoît Malon, early editor of the journal and an Independent socialist, wrote a series of articles in early 1886 on "Les Morales religieuses", in which he condemned Judaism on ethical grounds. ${ }^{10}$ He found too much cruelty and too little compassion in the Bible, com-

7 Drumont, La France juive, I, p. 530.

${ }^{8}$ Cf. Wilson, Ideology and Experience, op. cit., ch. 11, "Socialist Anti-Semitism: 'A Kind of Socialism" ", for a good discussion of the "socialism" (populism) of the antiSemites, and pp. 334-39 on the anti-Semitism of the socialists.

${ }^{9}$ Benoît Malon was editor until 1893; Alexandre Millerand from 1893 to 1896; Jules Guesde for a short period in 1896; then Alfred-Léon Gérault-Richard from 1896 to 1898 and Jean Jaurès from 1898 to 1904.

${ }^{10}$ B. Malon, "Les Morales religieuses", in: La Revue Socialiste (hereafter RS), III (1886), pp. 1-17. 
menting that the Bible stories were largely motivated by threats: that the Jews were threatened by God to obey His laws; that they were promised riches if they did obey and therein lay the basis of Jewish materialism. (Although Malon's analysis is interesting it seems to be unique. Either other socialists did not read the Bible or they found such an argument irrelevant; no other author attributed Jewish acquisitiveness to the fear of God.)

In a similar vein, the journal ran an eight-article series that appeared from 1887 to 1889 by the Blanquist A. Regnard, entitled "Aryens et Sémites: Le Bilan du Christianisme et du Judaïsme", in which Regnard combined anti-religious and racial anti-Semitism, arguing that the antique race of Aryans which had represented the ideal state of humanity had been ruined by the Judeo-Christian heritage, which latter furthermore had led inexorably to capitalism, the worst evil of them all. Regnard propounded a battle against all three historical plagues - Semitism, Christianity and Capitalism -, and he dealt at length with the purity of the Aryan race, quoting Ernest Renan that the Jews were an "inferior combination of human nature". Regnard included the usual descriptions of Semitic ugliness, even declaring in a footnote that "the Jews share with the Patagonians the uniqueness of having the longest noses that exist in the world"!!

More along the lines of Drumont, there had appeared in September 1885 an article by Auguste Chirac, a regular contributor, entitled "Les Rois de la République: Histoire des juiveries", excerpted from Chirac's book by that name which had appeared in $1883 .^{12}$ The journal gave more extensive coverage to Chirac's theories in a long series of articles by him from 1885 to 1888 , entitled "L'Agiotage de 1870 à 1884 ", in which Chirac's hostility to capitalism and particularly to finance capitalism was translated into numerous attacks against "the Jewish bank", "the Jewish usurer" and, more generally, "the baneful influence of Jewish dealings". ${ }^{13}$

When Drumont's La France juive appeared in 1886, Malon complimented parts of Drumont's social program, especially praising Drumont's emphasis on the possibility of a peaceful transition to workers' control. ${ }^{14}$ Malon was apparently on cordial terms with Drumont and, while criticizing

11 RS, V (1887), pp. 499-518; VI (1887), pp. 26-46, 383-403; VII (1888), pp. 473-90; VIII (1888), pp. 70-82, 168-78; IX (1889), pp. 171-89; and X (1889), pp. 401-21, all of which were published as one piece by E. Dentu (Paris) in 1890 .

12 A. Chirac, Les Rois de la République: Histoire des juiveries (2 vols; Paris, 1883).

${ }^{13}$ Id., "L'Agiotage de 1870 à 1884", in: RS, IV (1886), p. 605. The entire series ran from November 1885 to January 1888 and was reprinted as a book entitled L'Agiotage sous la Troisième République, 1870-1887 (Paris, 1888).

14 B. Malon, "La Question juive”, in: RS, III, pp. 505-14. 
the latter for his narrow clericalism, he emphasized, however, that Drumont's program could only be a start. All capital, not just Jewish capital, had to be the target of a socialist take-over.

Gustave Rouanet, also an Independent socialist, reviewing La Fin d'un monde, another of Drumont's books, in La Revue Socialiste in 1888, was even more sympathetic to Drumont. Like Malon, he criticized Drumont's Catholic chauvinism and reactionary tendencies, but complimented Drumont for the section of La Fin d'un monde devoted to a socialist proposal for the future. Rouanet also commended Drumont for pointing out the evils of Jewish capitalism, elaborating that the natural antagonism between the Jewish and Aryan races was exacerbated by the Jews' monopoly over wealth. This second, economic antagonism between capitalists and proletarians only worsened the natural racial antagonism that already existed. Rouanet admitted that there were Aryan capitalists as well as Jewish capitalists, but he claimed that the comparative number of Jewish capitalists was growing much more rapidly and that in several years all of French civilization would be in their hands. "The dominant tendency of the Jewish people [peuple d'Israël] is the monopoly of exchange values." 15

\section{Evaluating the symptoms}

How must this socialist anti-Semitism be evaluated? Was it fundamental to the socialist theories of these writers? For Toussenel perhaps, for Tridon and Chirac maybe, but they are more often cited for their anti-Semitism than their socialism. (And for Drumont, it is clearly rather his "socialism" which is ancillary to his anti-Semitic theme.) In general the socialists" critiques of capitalism's malady and their visions for its cure could stand alone without any reference to the Jews.

But can the persistent interjection of different types of anti-Jewish epithets nonetheless be dismissed as inconsequential? Neither the religious nor the economic component of anti-Semitism were new to the nineteenth century, of course. The long history of religious antipathy toward the Jews needs no introduction, and neither does the hostility toward the Jews as usurers, dating back to the Middle Ages, for the very economic role to which they had been relegated. It must be noted, however, that the "religious" component of socialist anti-Semitism was fundamentally different from the usual clerical attacks against the Jews. It was basically anticlerical, coming from a freethinking Enlightenment critique of religion in general. The Jews were no longer blamed for killing Christ but, on

15 G. Rouanet, "Revue des livres”, in: RS, VIII, p. 662. 
the contrary, for having invented him!16 As for racialism, the "scientific" theories of Gobineau and the linguistic studies of Renan took on increasing importance at the end of the nineteenth century when, in the period between the Franco-Prussian War and World War I, these theories became a useful adjunct to nationalistic propaganda. The socialists were not impervious to the growing fascination with these new theories.

More interesting with relation to socialist thought, however, is the economic component of socialist anti-Semitism. One could ask whether Jewish capitalists are being blamed primarily as Jews or primarily as capitalists. In the first case, if Christian capitalists are neglected, then the critique is an anti-Semitic one, not a socialist one. In the second case, if the emphasis is truly anti-capitalist, perhaps the Jewish angle is insignificant and the critique not anti-Semitic at all. In fact, however, the lines were never drawn so clearly. And furthermore, where anti-Semitism and anticapitalism appear together it is not only when the capitalists involved are only Jews or vice versa. An amalgam occurs whereby all Jews are supposed to be capitalists and all capitalists are supposed to be "Jews", regardless of their origin.

In the latter case it is necessary to understand the meaning of the term juiverie and its uses in the nineteenth century in order to comprehend the socialist form of economic anti-Semitism, whether against commercial or financial capitalism. In some cases, as Madeleine Rebérioux has pointed out, the concept of juiverie was used in the nineteenth century "in the absence of any juif, in order to designate any comportment that was adjudged scandalous". ${ }^{17}$ For Toussenel the word Juif came to mean all foreigners. ${ }^{18}$ Auguste Chirac identified different kinds of juiveries - juiverie israélite, juiverie chrétienne, juiverie protestante and juiverie jésuite - in his history of juiveries, and defined "Jewish dealings" as "usury, parasitism, theft, anti-socialism, in a word, all just as much the work of Christians as of Jews [Juifs]". ${ }^{19}$ This anti-Semitism, as translated in the language and codified in the dictionaries, was part of the nineteenth-century vocabulary. ${ }^{20}$

16 As pointed out justly by Lévy, L'Idéologie française, op. cit., p. 129.

17 M. Rebérioux, La République radicale? 1898-1914 (Paris, 1975), p. 32.

18 Poliakov, Histoire de l'antisémitisme, op. cit., III, pp. 383-84.

${ }^{19}$ Chirac, Les Rois de la République, op. cit., I, chs 4-7, and id., letter to Drumont in RS, V, pp. 84-85.

${ }^{20}$ In Vol. IX of the Larousse Grand Dictionnaire Universel du XIXe Siècle, published in 1873 , Israélite appeared in colloquial usage in the phrase "Bon Israélite" ("applied by Jesus to St John, and still used today to designate an honest and forthright man"), whereas Juif could designate in colloquial usage "a person who practices usury, who sells extremely dearly; a person who earns money through unjust and sordid means". A rather 
In the linguistic equation between capitalist and Jew, the socialists thus inherited a language in which the negative characteristics ascribed to all capitalists were also attributed to all Jews. Yet the French language, with the distinction between Juif and Israélite, offered a possibility of distinguishing between the Jewish people per se (Israélite) and the economic function (Juif) which they were held to embody. ${ }^{21}$ Gustave Rouanet later apologized for this confusion by explaining that "Juifs, Juiveries [were used in] a literary sense, [in] the vulgar meaning which the people attach to these words. These terms were simply supposed to mean 'usurers', 'monopolists'." 22 Nonetheless it was Juif and not chrétien which was used and which lurked in the language, difficult to expurgate even when apologetics were in order. It may have been clear to the socialists that by Juif only Rothschild and other representatives of modern finance were meant, but can it be assumed that the people who read "A bas les Juifs!" knew exactly which Juif/Israélite was intended? ${ }^{23}$

The vocabulary chosen is important, and to deny any real significance to this usage of anti-Jewish epithets is too generous. Even while understanding the anti-Semitic vocabulary in its nineteenth-century context, it cannot be dismissed as totally "irrelevant" just because it was standard and wellused. ${ }^{24}$ Economic, religious or racial anti-Semitism was employed by the socialists to make a specific and larger point; it was an effective tool given the symbol of the Jew as synonymous with the rise of commercial and finance capitalism. However, that symbol was never carefully examined. Nor did it become evident until the publication of Edouard Drumont's $L a$

apropos, for our purposes, example of the usage of the term Juif was given from Balzac: "Tous les banquiers ne sont pas des Juifs. Tous les Juifs ne sont pas en Israël." (A polemic over these dictionary definitions occurred again recently in a French lycée, Le Monde, April 8-9, 1979.) See also Glasberg, "Intent and Consequences", loc. cit., p. 66. 21 The French Jewish community itself, especially after the French Revolution, encouraged a distinction between the two terms in order to distinguish itself, as Israélites, from the atavistic Juifs of ghetto days. P. Girard, Les Juifs de France de 1789 à 1860: De l'émancipation à l'égalité (Paris, 1976), pp. 140-42; D. Schnapper, Juifs et Israélites (Paris, 1980). Although there is no real equivalent in English, a differentiation of this sort, although less pronounced, is made by using the noun instead of the adjective, as in "(S)he is a Jew" rather than "(S)he is Jewish."

22 G. Rouanet, "La Question juive et la question sociale", in: RS, XI (1890), p. 220. Pierre Leroux also explained his usage of the term by appealing to an Académie Française definition of Juif. Poliakov, Histoire de l'antisémitisme, III, p. 385.

23 Glasberg, "Intent and Consequences", p. 64.

${ }^{24}$ Lichtheim, "Socialism and the Jews", loc. cit., p. 317. Glasberg, in his otherwise interesting article, also goes too far when he exculpates Chirac and Malon in concluding: "In fact, the anti-juif socialists, far from indulging in antisemitism, clearly and categorically repudiated it." "Intent and Consequences", p. 70. 
France juive and the development of a political anti-Semitic movement at the end of the century how dangerous that symbol could and had become.

The unreflecting usage of this linguistic equation resulted from a failure to understand the uses and consequences of anti-Semitism. This was possible because it was ingrained in a nineteenth-century vocabulary which the socialists had little reason to question until the end of that century. And even then the response would at first be equivocal. At the second congress of the Second Socialist International in Brussels in August 1891, two French delegates, Regnard, seconded by another Blanquist, Paul Argyriadès, argued, in relation to a proposed resolution denouncing antiSemitism in Russia, that while anti-Semitic excitations should be denounced, so should "philo-Semitic" ones. ${ }^{25}$ In a preview of the GuesdistBlanquist attitude toward the Dreyfus Affair, Regnard's thinking carried the day, and the resolution against anti-Semitism and philo-Semitism was voted as a denunciation of all racial or nationalistic antagonisms. Only the class struggle was recognized as worthy of discussion; all other cleavages would be resolved with the coming of socialism.

Yet some perceived the danger in anti-Semitism as early as the first printing of La France juive. As Malon and Rouanet had mentioned, Drumont's hatred of anything non-Catholic was entirely consuming. He exaggerated wildly and linked the Jews to all of the qualities of mankind he disliked. Even Chirac criticized Drumont's "Christian pseudo-socialism" and faulted him for ignoring that Christians as well as Jews were able exploiters, although Chirac was basically peeved that Drumont had ignored his own, earlier, writings on the subject. ${ }^{26}$

Through the crucible of the Dreyfus Affair the capitalist=Jew equation would have to be re-examined along with the anti-Semitic vocabulary through which it was expressed. First, the misnomer of juiverie would become evident. Malon and Chirac had already seen the importance in specifying that not all capitalists were Jews, but this point would become increasingly pertinent as the dreyfusard and anti-dreyfusard factions were analysed. Next, the premise would be inverted: nor were all Jews capitalists.

25 See L. de Seilhac, Les Congrès ouvriers en France de 1876 à 1897 (Paris, 1899), pp. 222-23; A. Veber, "Le Congrès de Bruxelles", in: RS, XIV (1891), p. 355; E. Silberner, "Anti-Semitism and Philo-Semitism in the Socialist International", in: Judaism, II (1953), pp. 117-22. Cf. statement of the Blanquist Comité révolutionnaire central in 1897 when it declared it was "as opposed to anti-semitism as it was to the Jews", quoted in Cahm, "Socialism and the Nationalist Movement", loc. cit., pp. 53-54.

26 Chirac, letter to Drumont, loc. cit. 


\section{The Dreyfus Affair and the socialists}

The Dreyfus Affair was a bourgeois struggle. Guesde defined it as such and Jaurès agreed. As anti-dreyfusards confronted dreyfusards, the battles of the French Revolution were fought anew. At the same time the emancipation of the Jews during the French Revolution was also replayed a century later. For the French socialists the Dreyfus Affair meant taking a stand not only on the issue of anti-Semitism, but on the side of one of the ruling-class fractions at odds in this bourgeois struggle. This implied identifying the more "progressive" fraction of the bourgeoisie, and one of the signal factors in that process of differentiation was understanding the reactionary uses of anti-Semitism on the part of the anti-dreyfusard and anti-republican faction.

Already in 1890 , four years before Dreyfus' arrest, the anti-republican danger of anti-Semitism became crystal-clear to Gustave Rouanet. In a remarkable turnabout from his earlier appreciation of Drumont, he wrote an article entitled "La Question juive et la question sociale". Rouanet once again summarized Drumont's hatred of the Jewish race and repeated Drumont's assertion that the Jews were the cause of all modern ills, including "proletarian misery, social conflicts, [and] the vices of our economic system". ${ }^{27}$ But this time Rouanet disagreed with Drumont. The reason was a recent meeting in Neuilly, organized by the newly constituted Ligue antisémitique of Drumont. This meeting, which has been called the "veritable birthdate of the [political] anti-Semitic movement" in France, ${ }^{28}$ had made it all too clear to Rouanet exactly how anti-Semitic excitations such as Drumont's could feed into the growing anti-republican movement: "Political interests thus hide behind anti-Semitism." 29 But for Rouanet those political interests could masquerade behind pseudo-socialistic rhetoric no longer, and he questioned "the good faith of these revolutionary neophytes" ${ }^{30}$ He charged the Catholic and conservative parties with being instead the very blockades to any amelioration of social conditions which only the Republic had finally been able to provide. He decried these enemies of the Republic, who understood too well how Drumont's "vigorous campaign against the Jewish Republic [could be used as a] considerable prejudice against the Republic per se". ${ }^{31}$

Rouanet systematically defeated the Neuilly claims. Dealing first with

${ }_{27}$ Rouanet, "La Question juive", loc. cit., p. 221.

28 Sternhell, La Droite révolutionnaire, op. cit., p. 205.

${ }^{29}$ Rouanet, "La Question juive", p. 223.

30 Ibid., p. 220.

31 Ibid., p. 223. 
the very phrase "Jewish Republic", he gave a short historical analysis of the nineteenth century. Without malice he stated that Jewish capital had been "all-powerful" during every regime since $1815 \ldots$ in order to prove that the Republic had no monopoly on Jewish financiers. Rouanet then proceeded to prove that "the war against the Jewish capitalists" is a "chimera". ${ }^{32}$ There is no basis for separating Jewish capitalists from Christian capitalists, he insisted; the two are inextricably linked. As for the racial attacks of the anti-Semites, Rouanet dismissed them also. History had proven the adaptability of the Jews for, starting out as a biblical, pastoral people, they had, through the years, adjusted admirably . . . to commerce. But wasn't it obvious that these were acquired habits due to the economic role to which the Jews had been relegated?

Rouanet concluded by emphasizing that the Jewish question was only one aspect of the "social question". As such, anti-Semitism, both in its racial and economic forms, would be solved along with the larger social question with the triumph of socialism that would eventually exorcise this evil as well as all others: "Socialism works towards racial equality and against economic inequalities". ${ }^{33}$ Perhaps realizing that he himself had almost been duped by the anti-Jewish-capitalist line, Rouanet now warned others of the pernicious nature of anti-Semitism, reminding them in the end of the curative powers of socialism.

If Rouanet had realized the anti-republican danger behind anti-Semitism, not everyone agreed with him. Regnard, the author of "Aryens et Sémites", responded to Rouanet's article in the next issue by rejecting the idea that socialism should pursue racial equality ${ }^{34}$ Instead he argued that by adopting "the race struggle" socialism should rightfully defend the superior Aryan race against the deplorably inferior Jewish race. The Aryan struggle against Jews was but another manifestation of the proletarian struggle against capitalists for "capitalism is a Semitic creation", wrote Regnard. He further refused to accept any historical/environmental apologies for Jewish capitalism. "One doesn't become a usurer by the force of events; one is born thus!" He concluded by admitting to honorable exceptions among the Jewish race, e.g., Spinoza, Marx and Lassalle, but he explained away these exceptions by stating that "they placed themselves spontaneously outside of Judaism".

In the same issue, Malon responded to Regnard's letter in a conciliatory manner by concluding that Rouanet's essay had been nothing more than a

32 Ibid., p. 229.

33 Ibid., p. 234.

34 A. Regnard in RS, XI (1890), pp. 348-49. 
response to a specific political event - i.e., the Neuilly meeting -, which therefore did not necessarily contradict the ethnic-historical work of Regnard. The equivocations of the socialists with regard to anti-Semitism were thus still present. Rouanet, for one, had recanted and saw the necessity of attacking anti-Semitism frontally in order better to defend the Republic, but the Dreyfus Affair itself would bring the issue more starkly to the fore.

Dreyfus was arrested for treason in 1894, quickly condemned and sent to languish on Devil's Island, while the movement for his defense grew slowly over the next four years. ${ }^{35}$ On January 13, 1898, the publication of Zola's famous $J^{\prime}$ Accuse! forced the Affair back into the public eye, and the parliamentary socialists met several days later to discuss the issue. Jaurès, already convinced of Dreyfus' innocence for some time, felt the battle for Dreyfus should now be engaged by all socialists. Several other Independent socialists (e.g., Viviani and Millerand) were hesitant, however, because elections were coming up in May. ${ }^{36}$ Guesde called Zola's $J$ 'Accuse! the most revolutionary act of the century, but he and the Blanquists warned against engaging the proletariat in what was essentially a bourgeois struggle. In spite of these differences they all finally agreed to support a Manifeste du Groupe socialiste parlementaire.

The manifesto rejected taking sides in the Dreyfus Affair. The reason was that the Affair was a bourgeois struggle, participation in which would only divert the proletariat from the class struggle. On one side of this bourgeois struggle were the clericalists, who, by denouncing one Jew, sought to "disqualify all Jews and with them all dissidents, Protestants or freethinkers" ${ }^{37}$ On the other side were the Jewish capitalists, who, still recovering from the several financial scandals which had blackened their image in recent years (e.g., the Panama Scandal), sought to vindicate all Jews through Dreyfus.

Both Guesde and Jaurès were represented in the agreed-upon compromise. One line of the manifesto, clearly speaking for Jaurès, read:

${ }^{35}$ The most recent general work on the Dreyfus Affair is J.-D. Bredin's interesting L'Affaire (Paris, 1983).

${ }^{36}$ See Cahm, "Socialism and the Nationalist Movement", for an interesting if somewhat overdrawn distinction between the timidity of parliamentary socialists in coming to Dreyfus' defense as compared to the boldness of the extraparliamentary Allemanists and anarchists, who, uninhibited by electoral politics, had freer reign in condemning the antiSemitism and nationalism of the Affair. Persistent anti-dreyfusism and anti-Semitism among certain anarchists and anarcho-syndicalists cannot be ignored, however, e.g., J. Grave's Les Temps Nouveaux and E. Pouget's Le Père Peinard. See also Wistrich, "French Socialism and the Dreyfus Affair", loc. cit., and Sternhell, La Droite révolutionnaire, for distinctions between different leftists' attitudes.

37 A. Zévaès, Le Socialisme en France depuis 1871 (Paris, 1908), p. 279 
"Certainly, the proletariat [ . . ] must not be insensitive to injustice, even if it strikes a member of the enemy class." ${ }^{38}$ Yet the pro-Guesdist conclusion was that the proletariat must not be duped by the patriotic/nationalistic propaganda on the one hand and the appeal to the rights of man on the other. The proletariat had to realize that these bourgeois factions, at war with each other today, would join hands tomorrow in reinforcing the oppression of the working class and the workers' movement. The manifesto continued by denouncing Drumont's brand of anti-Semitism, which saw only the Jews as capitalists.

We, socialists, we do not make a distinction between Jewish capitalism and Christian capitalism. [. . .] Cry out your triple war cry: War against Jewish or Christian capitalism, war against clericalism, war against the military oligarchy! $!^{39}$

Thus in January of 1898 the fractions of the bourgeois struggle were identified and Drumont was denounced, but the socialists were not yet ready to defend the bourgeois Jew Dreyfus. However, the socialist unity behind that decision was fragile, and the argument over participation in the Dreyfus Affair was a reflection of the diverse segments of the French Left at the end of the nineteenth century. The differences between socialist groups were largely defined over the issue of universal suffrage - bourgeois electoral politics - as a terrain for socialist participation, and it was just such a question of participation on the bourgeois terrain which came to the fore in the Dreyfus Affair, as it would with Millerand's entry into the government in 1899 and with the voting of war credits fifteen years later.

The Union Socialiste - the parliamentary socialists from Blanquists to Possibilists, who had joined forces in 1893 and consolidated their unity in 1896 with the Programme de Saint-Mandé - which agreed to the January 1898 manifesto did not stay unified for long. It was Jaurès, the most famous of the Independent socialists, who broke that solidarity only a few weeks later when he testified at Zola's trial: "Never has the Republic faced a comparable danger". ") Jaurès decried the dangers of anti-Semitism, clericalism and militarism, and insisted that Dreyfus must be actively

38 Ibid, p. 280.

39 Ibid., pp. 282-83.

41) A. Zévaès, Histoire du socialisme et du communisme en France de 1871 à 1947 (Paris, 1947), p. 264. On Jaurès see M. Rebérioux, "Classe ouvrière et intellectuels devant l'Affaire: Jaurès", in: Les Ecrivains et l'affaire Dreyfus, ed. by G. Leroy (Paris, 1983), pp. 185-95; id., "Zola, Jaurès et France: trois intellectuels devant l'Affaire", in: Cahiers Naturalistes, No 54 (1980), pp. 266-81; and H. Goldberg, "Jean Jaurès and the Jewish Question", in: Jewish Social Studies, XX (1958), pp. 70-93. See Jack Jacob's article in this issue concerning Kautsky's high praise of Jaurès' stand on the Affair. 
defended by socialists as well as by justice-minded republicans. In the May elections Jaurès lost his Chamber of Deputies seat, undoubtedly for his strong defense of Dreyfus, but then Guesde lost his seat also. In or out of Parliament the socialists were now disunited over the Dreyfus issue.

The Blanquists and Guesdists supported the January manifesto to the extent of actively working against Jaurès. ${ }^{41}$ They insisted that any involved defense of Dreyfus. would only distract the workers and would in fact constitute an implicit collaboration with (albeit progressive members of) the bourgeoisie. In July Guesde's Parti Ouvrier Français issued a statement to the workers of France urging them to refrain from taking sides in this bourgeois quarrel, "this battle, which is not theirs". ${ }^{42}$ The POF allowed that it was important to unmask the false democratic propaganda of antiSemitism and expose its true reactionary character, but aside from that task the socialists should not deviate from their "proper war" against the entire bourgeois class.

The Possibilists on the other hand joined Jaurès in actively defending Dreyfus, insisting that any oppressed individual deserved justice. As for the Allemanists and the anarchists around Sébastien Faure, they had supported Dreyfus even before Zola's J'Accuse!, and it was they who physically broke up an anti-Semitic meeting on January 17 protesting Zola's publication. ${ }^{43}$ Two events occurred several months later, however, that finally convinced the Guesdists and Blanquists that socialist unity, this time in Jaurès' favor, was imperative.

On August 30, Lieutenant-Colonel Henry confessed to having forged the documents that had convicted Dreyfus. Henry was arrested, jailed and found dead in his cell the next day, his suicide another form of confession. Public opinion for the most part shifted rapidly in favor of the dreyfusards. But several nationalist and anti-Semitic organizations only renewed the vigor of their attacks. In September and October bands of anti-dreyfusards roamed through Paris and other cities, breaking up dreyfusard meetings and shouting "Vive l'armée" and "Mort aux Juifs". At the same time several major strikes broke out in Paris. Troops which had been called in to quell strikes earlier in the summer were still there, and rumors spread that a military coup was being planned. There was real fear for the sanctity of the

41 With notable exceptions such as the Blanquist Emmanuel Chauvière and the Guesdist Paul Lafargue. On the Guesdists and the Affaire see C. Willard, Les Guesdistes (Paris, 1965), ch. XXI.

42 Zévaès, Le Socialisme en France, op. cit., pp. 286-88.

43 Cahm, "Socialism and the Nationalist Movement", p. 57. 
Republic. In this atmosphere the socialists united once more on the subject of Dreyfus. Realizing the ultimate danger of the anti-dreyfusard forces, the Guesdists and Blanquists initiated a Comité de Vigilance, joined shortly by the Possibilists, Independents and Allemanists. Another manifesto was drawn up, this time in favor of Dreyfus, ending with the words "Vive la République sociale."

A year later, at the first Congrès Général des Organisations Socialistes Françaises (Paris, December 1899, also known as the Congrès de la Salle Japy), a motion was presented on the attitude to be taken with regard to militarism, clericalism, anti-Semitism and nationalism. One speaker appealed to socialist unity (the purpose of the congress after all), warning against a re-awakening of old dissensions over this motion. In any case the Congress was coming to an end and there was little time left for discussion. The following statement was finally adopted unanimously: "The Congress castigates all nationalists and anti-Semites, and warns the workers against all forces of reaction." 44 The fear of "philo-Semitism" had finally been purged.

The Republic was in danger, and it was, after all, the terrain upon which the socialists were struggling to better workers' conditions. In protecting that terrain they were re-asserting their commitment to electoral politics and revolutionary change, and the importance of socialist unity to effect any change. In recognizing the threat of reaction represented by the Affair and partaking in the fray the socialists chose preservation of the Republic as their first task. Just as bourgeois electoral politics no longer fell outside the scope of a socialist strategy, so bourgeois squabbles and anti-Semitism no longer fell outside of the socialists' sphere of concern.

The positions taken by the socialists with regard to the Affair in 1898 were but a prelude to the rifts provoked a year later by Millerand's entry into the (bourgeois) government in June 1899. In Jaurès' debate with Guesde on the subject in 1900, he referred to the Affair as the true origin of their differences of method. ${ }^{45}$ The Jauressian method, that which became dominant with regard to the Affair (and which admitted Millerand's participation in the bourgeois government), was not only a position of defense of the Republic, to protect the very gains of the French Revolution, and to defend the oppressed and protect humanitarian justice ... even for a member of the bourgeoisie. (Dreyfus "is no longer an officer nor a

44 Congrès général des organisations socialistes françaises (tenu à Paris, Décembre 3-8, 1899) (Paris, 1900), p. 399.

15 J. Jaurès and J. Guesde, Les Deux méthodes, 2nd ed. (Paris, 1925), pp. 3-4. 
bourgeois: [ . . .] he is nothing more than humanity itself". ${ }^{46}$ ) It was also an important re-interpretation of the class struggle vis-à-vis the Guesdist Marxists. Quoting Marx himself, Jaurès pointed out that it was necessary to distinguish among the fractions of the bourgeoisie ("We, revolutionary socialists, we are with the proletariat against the bourgeoisie, and with the bourgeoisie against the squires and priests") in order to prevent the "offense and return of feudal barbarism and the all-powerful Church". ${ }^{47}$ The monarchical, clerical fraction of the late-nineteenth-century ruling class had to be beaten in favor of the republican elements.

This identification of fractions within the bourgeoisie was important for a re-evaluation of socialist anti-Semitism and the Jewish question in general. Anti-Semitism had been defined by Jaurès and Guesde alike as a struggle among different fractions of the bourgeoisie, but the Guesdist decision to declare such intra-class battling as unimportant to the immediate struggles of the working class meant ignoring the implications of those internecine bourgeois battles - both as to how they could shape the terrain of the larger class struggle and how they could wilfully distract the proletariat from it.

However, by taking sides in that bourgeois struggle along the lines of Jaurès' argument (to which the Guesdists finally rallied in the spirit of socialist unity and defense of the Republic) the non-sense of the old term juiverie would become evident. For the bourgeoisie was fractioned, among other things, into Christian and Jewish components. Chirac had admitted it, Rouanet had apologized for the confusion, and now in the polemic over the Dreyfus Affair it was made explicit.

The mechanism by which anti-Semitism was purged may thus be seen as threefold. First, there were the humanitarian arguments of Jaurès, based on an ideal of justice and the defense of the oppressed - whomever they may be. Second, the very interpretation of the class struggle was involved in choosing sides against anti-Semitism. Guesde's brand of Marxism allowed for a definition of anti-Semitism which defined it away to the future when socialism would solve everything. Jaurès had to quote Marx in order to offer another interpretation of the class struggle, in which the intra-class struggles of the bourgeois fractions were not only identified, but ultimately recognized as affecting the larger class struggle itself. Finally, the terrain on which that larger class struggle was taking place - the Republic, inheritor of the French Revolution - was in jeopardy. It took that specter of reaction to make the socialists aware of the dangers of anti-Semitism. If that specter,

46 J. Jaurès, Les Preuves (Paris, 1898), p. 12. Cf. id., Histoire Socialiste, XII, (Paris, 1900), p. 267.

47 Jaurès et Guesde, Les Deux méthodes, op. cit., pp. 10, 9. Guesde agreed, p. 25. 
along with the identification of bourgeois fractions in order to choose sides against the most reactionary of those fractions, also led some socialists further down a path of reformism, it nonetheless had the salutary effect of awakening them to the uses and consequences of anti-Semitic rhetoric.

In the pages of La Revue Socialiste the receding of anti-Semitism coincided both with the Dreyfus Affair and with Jaurès' editorship of the journal (1894-1904). Jews were now championed wherever anti-Semitism was found: in Austria, Russia, Algeria, Rumania. ${ }^{48}$ One author showed to what extent anti-anti-Semitism became pro-Semitism by pointing out that the Jews were model citizens in Algeria, paying their taxes promptly, providing for the education of their children and seldom getting drunk or divorced. He even excused those who were merchants, detailing why Jewish commerce, from shopkeepers to exporters, was a boost rather than a threat to Algeria. The connection between the defense of the Republic and anti-anti-Semitism was once again clear as he complimented the Algerian Jews for their "good, republican soul". ${ }^{49}$

The socialists now also argued explicitly against racial forms of antiSemitism. The sociologist Bouglé, in an article entitled "La Banqueroute de la philosophie des races", proved that there was no scientific basis to the racial aspects of anti-Semitism, for there could be no such thing as racial purity..$^{50}$ The French themselves, he argued, were but a mélange of various other peoples, and if the Jews had seemingly kept their community intact longer, it was due to historic conditions rather than any anatomical structure. Racial as well as economic forms of anti-Semitism were now criticized as being unhistorical. If the Jews had been associated with certain characteristics, it was due to their environment not their heredity. Rouanet, who had written of the natural and economic antagonisms between the Jewish and Aryan races in 1888, now in 1899 denied that the Jews were a race and countered that they were "a social product, an historical outcome". ${ }^{51}$

48 See B. Marie-Oswald, "Les Socialistes et les partis sociaux en Autriche", in: RS, XXVII (1898), pp. 448-63; H. J. Phalippou, "Juifs de Russie", in: RS, XXIX (1899), pp. 188-98; L. Durieu, "Le Prolétariat juif en Algérie", ibid., pp. 513-33; id., "La Naturalisation des Juifs algériens", in: RS, XXX (1899), pp. 1-12, 269-93, 436-62, 57390, 679-701; XXXI (1900), pp. 68-95, 200-22, 327-48; and G. Rouanet, "Les Juifs en Roumanie", in: RS, XXXVI (1902), pp. 82-106. Note also that Rouanet delivered a speech at the Chamber of Deputies on March 19 and 24, 1899, on "L'antisémitisme algérien".

${ }^{49}$ Durieu, "La Naturalisation", p. 590. Cf. Rouanet, "La Question juive”, p. 224, where he practically apologized for Rothschild.

so C. Bouglé, "La Banqueroute de la philosophie des races", in: RS, XXIX, pp. 385-94.

${ }^{51}$ G. Rouanet, "La Question juive", ibid., p. 84. See also E. Fournière, "Le Nationalisme", in: RS, XXXVI, p. 140. 


\section{Discovery of the Jewish proletariat}

Finally, the socialists' attitudes toward the Jewish question changed in one more significant way at the end of the nineteenth century. The Dreyfus Affair not only sensitized the socialists to the fact that not all capitalists are Jews; it also sensitized them to the fact that not all Jews are capitalists.

This first became obvious in the French socialists' own back yard. In 1886 Henri Tubiana, who signed his name followed by "israélite algérien", wrote a short article in La Revue Socialiste cautiously criticizing the "error" or "misunderstanding" of socialists in Algeria who had embraced antiSemitism unquestioningly. Tubiana pointed out that there was a sizable Jewish proletariat there, whose weakness vis-à-vis its rich co-religionists was worse than anywhere else. Perhaps significantly (fearing deaf ears?), Tubiana added: "This is due to causes which we will make known to the readers one day, if that can interest the readers of the Revue Socialiste." ${ }_{52}$ It apparently could, given Louis Durieu's series of articles on the Jewish question in Algeria running from 1899 to 1900 . At the same time H. J. Phalippou described the dreadful conditions of the Jews in Russia, and in 1902 Rouanet pointed to the poor artisanal Jews in Rumania. ${ }^{53}$

Between 1881 and World War I approximately 40,000 Jewish immigrants settled in France, fleeing economic and political oppression in Eastern Europe of a sort which made the anti-Semitism of the Dreyfus Affair pale by comparison ${ }^{54}$ They settled in Paris, for the most part, finding work in the light industrial sector, where homework persisted alongside family or contractors' workshops. $62.1 \%$ of the immigrants were skilled workers, $26.6 \%$ were merchants of one sort or another, $6.1 \%$ were peddlars, and $4 \%$ were professionals (including a large number of students). ${ }^{55}$ The Jewish immigrants became garment workers, woodworkers, leather workers, capmakers, in those expanding sectors where immigrant labor was more than welcome to cut costs, produce low-quality goods (imitation Louis $\mathrm{XV}$ furniture, rabbit furs) or provide a cushion of unemployment in the offseason. Not surprisingly, they by and large settled in the neighborhoods corresponding to their trades: garment workers in the Marais, woodworkers near the Rue du faubourg Saint-Antoine, students in the Latin Quarter. . .

52 H. Tubiana, "Les croisades au XIXe siècle", in: RS, IV (1886), p. 635 (emphasis added).

53 See note 48 .

${ }_{54}$ See Green, The Pletzl of Paris, op. cit.

s5 W. Speiser, Kalendar (Paris, 1910), pp. 78-80. Furthermore, $1.2 \%$ of the immigrants were listed together by Speiser as barbers, wigmakers, brushmakers, store clerks, lemonade makers and waiters. 
The discovery of the "proletarian" Jews thus occurred not only conceptually through the Dreyfus Affair, but concretely with the westward emigration of a class of Jews which implied once again a re-evalution of the idées reçues about the economic profile of the Jewish people.

In two particular instances in the Chamber of Deputies in the 1890's it was the socialists who reminded the Chamber of the existence of Jewish workers. The first was in 1891 when the socialist deputy Boyer made this point (in spite of interruptions from the right of "There are no Jewish workers!") in the context of the debate on a weekly restday - and why Sunday should not be imposed ${ }^{56}$ Another instance came during a debate on the Jewish question in 1895 . Rouanet and another socialist deputy Emmanuel Chauvière defended the Jews against Drumontian attacks on their "predominance" and "influence" in French society by arguing against the equation of Jews as capitalists ("venality is everywhere") ${ }^{57}$ Later, during the same debate, when the Jewish deputy Alfred Naquet said that if there were some Jewish capitalists that was no reason to attack the entire community, it was Guesde who interjected with the proof behind Naquet's remark: "There are classes within the Jewish race: there is a rich class and a proletarian class." Perhaps he had become acutely aware of this not only in theory, but in fact during a Guesdist meeting two years earlier in the fourth arrondissement, the district in Paris where most of the Jewish immigrant workers first settled, at which a resolution was passed condemning Drumont and all anti-Semites who hid behind socialism. ${ }^{58}$

It was in 1898, at the height of the Dreyfus Affair, that the Eastern European Jewish immigrants in Paris addressed themselves to the attention of the French socialists with an open letter entitled Le Prolétariat juif: Lettre des ouvriers juifs de Paris au Parti Socialiste Français. In the wake of the first manifesto, which rejected participation in the Affair as a bourgeois struggle, the Jewish workers criticized this stance of the French socialists and accused them of misunderstanding the real threat of anti-Semitism: "your attitude toward anti-Semitism is not frank enough, not indignant enough, not energetic enough, as it is in other similar cases where a

56 Archives Israélites (Paris, hereafter AI), December 31, 1891.

57 For these debates, see AI, May 30, June 6, 13 and 20, 1895. This liberal bourgeois Jewish paper was obliged to recognize then and in other instances the socialists as the only defenders of the Jews in the face of the "Silence of the French Parliament". See AI, July 19, 1906, along with AI, December 31, 1891, March 8, 1893, September 29, 1898, and July 2, 1908; and L'Univers Israélite (Paris), March 10, 1899. See also A. Naquet, "Discussions d'interpellations sur la question juive", in: Journal Officiel de la Chambre des Députés, May 27, 1895.

58 AI, March 9, 1893. 
principle of progress and humanity is at stake" ${ }^{59}$ Furthermore, the workers complained that the French socialists had ignored the Jewish proletariat, the "most proletarian people of the world. We are doubly so, as a class and as a nation; for we are both the pariahs of classes and the pariahs of nations." ${ }^{60}$ It was the Jewish proletariat which was the real victim of antiSemitism, "for the rich are too highly placed and the stones which are thrown at them do not reach them, but only fall back on the heads of the poor." 61

In September 1899 a meeting of Jewish workers took place which was one of the only public demonstrations of protest against the anti-Semitism of the Dreyfus Affair. Several French socialists and anarchists took part (among them Charles Malato, Louis Gérard, Louise Réville), who congratulated the Jewish workers on their initiative and condemned all attempts at fomenting a race war. Liberty, equality and fraternity were once again the order of the day, and the final resolution concluded: "Peace to all men and to all races." 62

The working through of leftist anti-Semitism, even when confronted with Jewish workers, was still not automatic, however. Anti-Semitism was now sometimes confounded not with anti-capitalism per se but, more specifically, with the protection of indigenous labor against migrant workers. At a July 1899 Conseillers Prud'hommes (conciliation board) meeting the need was felt to protest "energetically against certain workers who, under the pretext of nationality or religion, systematically shut out Jewish workers who come to their shops looking for work". Instead the Conseillers welcomed the Jewish workers while reiterating the belief in international solidarity:

All workers, no matter what nationality, race or religion, are brothers and have the same rights to work and to life. The Congress takes this occasion to salute the entrance of the Jewish workers' organizations into the struggle for the emancipation of the proletariat. ${ }^{63}$

59 Le Prolétariat juif: Lettre des ouvriers juifs de Paris au Parti Socialiste Français (Paris, 1898), p. 17. Cf. Wistrich's treatment of this letter, in his otherwise interesting article, "French Socialism and the Dreyfus Affair", p. 18. This letter is indeed an important critique of the French socialists by Jewish immigrant workers. However, Wistrich seems to imply that it revealed post-Dreyfus-Affair anti-Semitism when in fact the letter, published in 1898 , was clearly a response to the tergiversations of the socialists in that period.

${ }^{60}$ Le Prolétariat juif, p. 8.

61 Ibid., p. 18.

62 See Journal du Peuple (Paris), September 18, 1899; Les Droits de l'Homme (Paris), September 17 and 19; and L'Aurore (Paris), September 18.

63 XIXe Siècle (Paris), July 21 
Over a decade later, this time with regard to an important railroad strike against the Chemin de Fer du Nord, whose principal shareholder was the Rothschild family, the meaning of Juif once again became an issue. On April 3, 1911, at a meeting of the electric workers' union where Emile Janvion was speaking on "Freemasonry and the Working Class", Emile Pataud, secretary of the union, used the word Juif as synonymous with foe of the working class. Although no record of the meeting itself is extant, the anti-Semitic character of Pataud's remarks became infamous in the outrage which followed the meeting. Articles in L'Humanité and La Guerre Sociale sharply attacked Pataud, and nearly two thousand Jewish workers showed up at a protest meeting held at the Bourse du Travail on April 6. AntiSemitism was denounced as a sin and the motto of the International was recalled: to organize all workers without distinction of sex, race or religion. Along with Jewish Bundist speakers there were French socialists and notably Jean Longuet, who began his speech with: "The French Socialist Party is with you, Jewish workers!" 64 When Pataud tried to defend himself, saying that he had only meant to attack the big Jewish financiers as capitalists, he was booed in disbelief and a resolution was passed "desolidarizing" those present with the citizen Pataud. A week later the anarchists held a similar meeting at the Bourse du Travail (organized by Sébastien Faure), and called for yet another meeting two weeks hence under the auspices of the Clothing Workers' Union, which represented so many of the Jewish workers. Two years later, the Jewish union workers' organ, Der idisher arbayter, described the Pataud-Janvion Affair as second only to the Dreyfus Affair in helping purge the French left of antiSemitism..$^{65}$

Only eight months after the Pataud Affair, however, a tailor wrote in to La Guerre Sociale (the socialist-revolutionary paper edited by Gustave Hervé) complaining that the competition of Jewish tailors had caused him to lose his job, and that if there were an anti-Semitic movement he would join it.$^{66}$ Emile Pouget, a well-known revolutionary syndicalist, responded in the same issue by writing that "Jewish infiltration is one aspect of the issue of foreign competition", and that the Jews' solidarity leads to their

${ }^{64}$ Forverts (New York), May 5, 1911; AI, April 20, 1911; Z. Szajkowski, Di profesyonele bavegung tsvishn di yidishe arbeter in Frankraykh (Paris, 1937), pp. 37-44; and report, April 26, 1911, Archives of the Préfecture de Police, Paris (hereafter APP), BA 1423: Syndicat général, Travailleurs de l'habillement, 1909-18. According to Marc Jarblum Longuet, Marx's grandson, used to say: "I don't know exactly what percentage of Jewish blood I have in my veins, but I consider myself one-fourth-Jewish." M. Jarblum, "Deux rencontres avec Lénine", in: Les Nouveaux Cahiers, No 20 (1970), p. 8. ${ }_{65}$ Der idisher arbayter (Paris), August 9, 1913.

of La Guerre Sociale (Paris), December 20-26, 1911. 
"insinuation" into a workshop once one of their members has "penetrated" it. The several letters of criticism which this answer provoked compelled Pouget to respond two issues later. The title of his second article (January 3-9, 1912), "La question des étrangers - Le péril antisémite", marked a significant change of tone from the first, "La question des étrangers L'invasion". Although Pouget began this apology in rather suspect terms, saying that he did not want the "sensitive skins" of "our Jewish comrades" to "shudder" any longer and that blind philo-Semitism was no better than blind anti-Semitism, he went on to commend the Jewish militants who had written in. He re-iterated that the essential battle to be fought was that against the bosses, while the double peril of anti-Semitism and nationalism had to be exorcised.

The process of purging anti-Semitism was not an easy one and sometimes faltered in the face of labor protectionism, but whenever the Jewish workers made their presence felt, the ideology of international workers' solidarity was re-iterated and the mystification of anti-Semitism denounced once more. The motto of the Communist Manifesto was repeated and embellished for the occasion: Workers of all countries unite, regardless of race, nationality or sex.

In the period between the Dreyfus Affair and World War I the discovery of the Jewish proletariat by the French labor movement took place in two ways - encounters on the union level and encounters in the political realm, where French socialist contacts with Russian social democrats (in Paris since the late 1870's) offered another meeting with Jewish immigrants. Protest meetings took place against the Kishinev massacre of Jews in 1903, against the "massacres of revolutionaries, intellectuals, Jews and Armenians" in late 1905, against the Tsar's visit to France in 1910, and against the Beilis Affair in 1913, which brought French leftists such as Jaurès, Francis de Pressensé, Pierre Quillard, Louis Dubreuilh and others together with Russian Jewish social democrats - intellectuals and workers - in a denunciation of the Tsarist regime and its anti-Semitic manifestations. ${ }^{67} \mathrm{~A}$ fifthyear anniversary of the 1905 Russian Revolution also brought together Russian social democrats, Jewish workers and French revolutionary syndicalists. In addition to such encounters in joint protest over the outrages of the Tsarist regime, French socialists and Jewish immigrants also met at Jewish Bundist meetings where Marcel Sembat, Paul Louis, Edouard

${ }^{67}$ On Jaurès and the Kishinev meeting see J. Jaurès, "L'autocratie, voilà l'ennemi!", in: Les Nouveaux Cahiers, No 11 (1967), pp. 35-39; and M. Rebérioux, "Jean Jaurès et Kichinev", ibid., pp. 29-34. For other meetings see L'Univers Israélite, November 17, 1905; AI, April 11, 1912, October 23, 1913; Der idisher arbayter, March 7, 1914; and reports, November 19 and 21, 1913, APP, BA 1709: Russo-Juifs à Paris. 
Vaillant and Paul Lafargue among others came to give talks. ${ }^{68}$ The Jewish workers were welcomed to the French labor movement: "With the great sentiment of solidarity which moves us, we welcome your collaboration." ${ }_{69}$

As the Jewish workers organized, French union leaders came to speak at their meetings, and Yiddish-language trade sections of the CGT were formed in the period between 1900 and 1914. The Jewish capmakers, who represented over 80 percent of the workers in that trade, even formed their own union with A. Roux, the secretary of the French hatmakers' union, as their nominal head (in accordance with French law that restricted immigrants from leadership positions within unions), while Alexander Lozovsky was the de facto secretary. ${ }^{70}$

Roux, Pierre Dumas (secretary-general of the garmentworkers' union), Léon Jouhaux and others wrote occasional articles for the Jewish union workers' organ, Der idisher arbayter. Some were general articles discussing the CGT, the English work week, the workers' press, the anti-anarchist laws, etc. But others, particularly in the first and last issues of the paper (October 9, 1911, and July 4, 1914) sent "fraternal greetings" and congratulations to the Jewish workers - for their paper and for their organizing campaign. Unity with the French proletariat was proclaimed while differences among workers based on race, nationality or sex were disclaimed. In a few specific instances French union leaders were called upon to respond to charges of anti-Semitism. Forced to examine their positions, they explored the immigrant-labor question in Der idisher arbayter's pages, explained their remarks, and invariably ended with an appeal to workers' unity through union organization. ${ }^{71}$ Although theoretical unity sometimes still confronted protectionism on the shop-floor, and the Jewish workers organized, after all, as separate Yiddish-language sections, to the extent that they did become bevustzinike ((class-)conscious) they were welcomed by the French labor movement. ${ }^{72}$

Finally, specific efforts undertaken on behalf of Jewish immigrant workers in conflict with their (immigrant) bosses or with the French bureaucracy can be mentioned. An important protest meeting of over 1,200 people was organized by the French garmentworkers' union on July 2,

${ }^{68}$ Bund Archives, New York, files "Pariz Bundisher Fareyn Kemfer Afishn" and "Kemfer".

69 Report, November 21, 1913, APP, BA 1709.

${ }^{70}$ Szajkowski, Di profesyonele bavegung, op. cit., p. 123. See also pp. 92, 97; and Green, The Pletzl of Paris, ch. 6.

${ }_{71}$ See articles by L. Toussaint (cabinetmakers' union) in Der idisher arbayter, November 17, 1911, and February 8, 1913, and by Pierre Dumas ibid., July 5 .

72 On the contradictions inherent in the creation of Yiddish-language sections, see particularly Green, The Pletzl of Paris, ch. 7. 
1914, to defend two Russian Jewish ready-to-wear tailors who had been arrested and expelled as a result of activities on May 1 of that year. Marcel Sembat declared that it was inadmissible that foreign workers be punished merely for striking. The meeting ended with "Vive l'Internationale". ${ }^{73}$ More amusing perhaps, but no less important in revealing the contacts now possible given the "discovery" of the proletarian Jew by the socialists, were two letters sent to the police department in 1915 on behalf of Russian Jewish taxi drivers who, although having passed all the required tests, were having difficulty getting their licences. The letters' authors were Longuet and Guesde. ${ }^{74}$

In 1898 Adolphe Tabarant wrote that socialist blindness to anti-Semitism had occurred because socialism had fallen asleep. ${ }^{75}$ Although there is some case for the argument that certain leftists became anti-Semitic (again) in the wake of disappointment over the consequences of the Dreyfus Affair, ${ }^{76}$ for the most part the turn of the century provides an interesting case-study of socialist evaluation and re-evaluation of anti-Semitism. As the mystification of Drumontian-style "socialism" became apparent and as the Eastern European Jews arrived, the distinction between a Jewish bourgeoisie and a Jewish proletariat would be recognized and the latter defended by the French socialists.

Was anti-Semitism a fundamental part of socialist discourse? When confronted with the implications of its use, it could be purged from the socialist line. Such purging was not easy and sometimes remained incomplete, even in the mouth of someone like Jaurès, who in a June 1898 speech said: "the Jewish race, single-minded, passionate and subtle, constantly consumed by a kind of fever, [ . . . is especially gifted at handling the capitalist system [ . . . But [ . . .] what we are saying to the people is this: If the whole of capitalism is detestable and iniquitous, why point particularly to Jewish capitalism [...]?"77 However, the old linguistic

${ }^{73}$ Report, July 2, 1914, APP, BA 1423; Archives Nationales, F ${ }^{7} 13740$ : Habillement, file "Presse 1914".

${ }^{74}$ Letters, September 29 and October 8, 1915, APP, BA 1709.

75 A. Tabarant, Socialisme et antisémitisme (Paris, 1898).

${ }^{76}$ See S. Fraisse, "L'antidreyfusisme de gauche entre 1906 et 1910", in: Les Ecrivains et l'affaire Dreyfus, op. cit., pp. 113-21; and the interesting article by Shlomo Sand, "Sorel, les Juifs et l'antisémitisme", in: Cahiers Georges Sorel, No 2 (1984), pp. 7-36. Sand explains how disappointment in the reformism of the Radicals and Combism, in the actions of a former Dreyfusard like Clemenceau, led a fraction of the Left to become post-Affair anti-dreyfusards, complete with a (sometimes quite virulent) anti-Semitic vocabulary.

77 Cited in Cahm, "Socialism and the Nationalist Movement", p. 59. 
equation was being questioned in 1898 and the Jewish proletariat would be welcomed within the next decade. Jaurès himself when faced with some of his pre-1900 generalizations about the Jewish race, would explain:

But those phrases with which you reproach me were written in the 90's, at a time when the role of Jewish finance appeared disproportionate to the percentage of the Jewish population in France and we ignored everything of the existence of poor Jewish artisans and workers. ${ }^{78}$

Thus the defense of a bourgeois Jew and the discovery of the Jewish proletariat helped cure French socialism of a pervasive anti-Semitic vocabulary. With the reactionary uses of anti-Semitism on the one hand and the immigration of Jewish workers on the other, the meaning of the term Juif had to be re-examined.

${ }^{78}$ M. Jarblum and J. Jemnitz, "Démocratie, question nationale, et sionisme en Europe centrale: qu'en pensait Jaurès?", in: Le Mouvement Social, No 52 (1965), p. 88. 